\title{
Characterization and compressive strength of fly ash based-geopolymer paste
}

\author{
Ari Widayanti ${ }^{1}$, Ria Asih Aryani Soemitro ${ }^{1}$, Hitapriya Suprayitno ${ }^{1}$, and Januarti Jaya \\ Ekaputri $^{1{ }^{*}}$ \\ ${ }^{1}$ Civil Engineering Department, Institut Teknologi Sepuluh Nopember, Surabaya, Indonesia
}

\begin{abstract}
Fly ash is a by-product obtained from coal combustion process. Some of the utilization of fly ash is to produce geopolymer products which have high compressive strength, fire, chemical resistance. This paper proposes fly ash from unit 1-7 Suralaya Power Plant Indonesia. The aims of this study are to obtain characterization of fly ash and mechanical properties of geopolymer paste based on variations of the alkali activator ratio. The method was based on previous research and laboratory investigation. XRF and compressive strength were analysed in this study. Alkali activator was obtained from $\mathrm{NaOH}$ and $\mathrm{Na}_{2} \mathrm{SiO}_{3}$ mixture. The ratio of $\mathrm{Na}_{2} \mathrm{SiO}_{3}$ to $\mathrm{NaOH}$ was in the range of $0.5-2.5$. Geopolymer paste was casted in acrylic cylinders with a diameter of $2 \mathrm{~cm}$ and a height of $4 \mathrm{~cm}$. The curing was conducted at room temperature until the day for the compressive strength test at 28 days. The result showed that the fly ash is classified as $\mathrm{F}$ class. Increasing the alkali activator ratio influenced the strength. The best composition of geopolymer paste is made with $\mathrm{NaOH}$ $8 \mathrm{M}$, and the mass ratio of $\mathrm{Na}_{2} \mathrm{SiO}_{3}$ to $\mathrm{NaOH}$ is 2.5. This composition produced compressive strength of 98.6 $\mathrm{MPa}$.
\end{abstract}

\section{Introduction}

The issue of environmental sustainability is one aspect that is currently being addressed by the United Nations. This is stated in the Sustainable Development Goals, such as the issue of the innovation of infrastructure. In this case research related to innovation in materials is also one part of innovation infrastructures.

The Indonesian Government in the RPJMN (Rencana Pembangunan Jangka Menengah Nasional) emphasizes the importance of infrastructure development in order to improve the distribution of people and goods that will have implications on the economic, political, social, cultural and security aspect. Building construction, bridges, highways and other kinds of infrastructure is one focus of the current government.

It needs a material that is light, has high strength, and is resistant to the influence of water and chemical absorption, and fire. The usage of cement needs to be limited, so as it can reduce $\mathrm{CO}_{2}$ emissions and considerations for environmental sustainability. On the other hand, fly ash is an abundant material, which will accumulate and if not used an it will cause

\footnotetext{
${ }^{*}$ Corresponding author: januarti@ce.its.ac.id
} 
waste and become dangerous goods. The process of generating electricity generates environmental waste from the coal combustion process.

Based on the data from Geological Agency of The Department of Energy and Mineral Resources (ESDM), there are approximately 65.4 billion ton of coal resources in Indonesia. One way to utilize coal is by using it as fuel for coal fired power plants (PLTU). Suralaya Power Plant Indonesia produces coal waste of 2.7 million tons per year and can continue to grow up to 11.2 million tons per year in 2027.

Fly ash is a by-product obtained from the coal combustion process. Fly ash production from Suralaya Power Plant is increasing, if not offset by maximum utilization then its existence will also damage the environment. The usage of fly ash must be done to reduce the fly ash accumulation and minimize the environmental impact. Fly ash is used as filler for both concrete and road pavement materials, and as an artificial aggregate in concrete.

Characterization of the forming material is one of the things that needs to be reviewed in generating material properties in accordance with technical specifications. Having known the characteristics of these materials, then the effect of material characteristics on the properties of material can be analysed.

The aims of this study were to obtain material characteristics and compressive strength of geopolymer paste based on fly ash.

\section{Literature review}

\subsection{Fly ash}

Based on ASTM C 618, fly ash is classified as follows:

- Fly ash class F. Fly ash contains silicon dioxide $\left(\mathrm{SiO}_{2}\right)$, aluminium oxide $\left(\mathrm{Al}_{2} \mathrm{O}_{3}\right)$, and iron oxide $\left(\mathrm{Fe}_{2} \mathrm{O}_{3}\right)$, which is more $70 \%$ by mass. It is produced from burning anthracite or bituminous coal (bituminous). Fly ash that also called the F-class or low-calcium fly ash, does not have cementitious properties and is merely pozzolanic. Fly ash class $\mathrm{F}$ is produced from burning anthracite or bituminous coal. It has pozzolanic properties. Fly ash requires the addition of quicklime, hydrated lime, cement to obtain the cementitious properties.

- Fly ash class C. Fly ash contains silicon dioxide $\left(\mathrm{SiO}_{2}\right)$, aluminium oxide $\left(\mathrm{Al}_{2} \mathrm{O}_{3}\right)$, and iron oxide $\left(\mathrm{Fe}_{2} \mathrm{O}_{3}\right)$, which is more than $50 \%$ by mass. It is generated from burning lignite or sub-bituminous coal (lignite/sub-bituminous). Fly ash class $\mathrm{C}$ is also called high-calcium fly ash. Due to a fairly high $\mathrm{CaO}$ content, fly ash class $\mathrm{C}$ has cementitious properties as well as pozzolan properties. Fly ash class $\mathrm{C}$ has pozzolanic properties and also has self-cementing properties (the ability to harden and add strength, when it reacts with water) and this nature occurs without the addition of lime. Although fly ash can be used in the form of dry or wet, fly ash is usually stored in dry conditions.

The most excellent Fly ash for the manufacture of geopolymer concrete is class F. Fly ash with a low calcium content is more widely used as source material when compared with fly ash class C. Due to the presence of calcium in high quantities contrary to the polymerization process and it can change the microstructure.

Production of fly ash in Indonesia increases in proportion to the consumption of the use of coal as a raw material from year to year. Fly ash is a mineral residue in fine grain produced from burning pulverized coal in a power station. Fly ash consists of inorganic material contained in the coal that has undergone fusion during combustion. The material solidifies while in the exhaust gases and is collected using an electrostatic precipitator. Because the particles condense when they are suspended in the exhaust gas, fly ash particles are generally spherical. Fly ash particles collected in a normally sized electrostatic 
precipitator has a size from 0.074 to $0.005 \mathrm{~mm}$. Today, generally fly ash is used in cement plants as an ingredient mix concrete. In addition, the actual fly ash has a variety of uses that are very diverse, namely: 1) the application of concrete for roads and dams, 2) stacking land formerly used for mining, 3) recovery of magnetite and carbon, 4) raw materials of ceramic, glass, stone brick and refractory, 5) abrasive materials, 6) filler asphalt, plastic, and paper, 7) substitute and cement raw materials, 8) conversion to zeolite adsorbent. Fly ash contains chemical elements: $\mathrm{SiO}_{2}$ (silica), $\mathrm{Al}_{2} \mathrm{O}_{3}$ (alumina), $\mathrm{Fe}_{2} \mathrm{O}_{3}$ (ferrous oxide) and $\mathrm{CaO}$ (calcium oxide). It also contains other elements: $\mathrm{MgO}$ (magnesium oxide), $\mathrm{TiO}_{2}$ (titanium oxide), $\mathrm{Na}_{2} \mathrm{O}$ and $\mathrm{K}_{2} \mathrm{O}$ (alkaline), $\mathrm{SO}_{3}$ (sulfur trioxide), $\mathrm{P}_{2} \mathrm{O}_{5}$ (phosphorus oxide) and carbon. The chemical composition, physical properties (color, particle size, density, specific gravity, moisture, fineness, loss of ignition, water absorption) of fly ash were influenced by the coal type, coal purity, destruction level, the type of heating and operation, methods of storage and stockpiling. Chemical requirements of fly ash is presented in Table 1.

Table 1. Chemical requirements

\begin{tabular}{|l|c|c|}
\hline \multicolumn{1}{|c|}{ Component } & \multicolumn{2}{c|}{ Class } \\
\cline { 2 - 3 } & F & C \\
\hline $\begin{array}{l}\text { Silicon dioxide }\left(\mathrm{SiO}_{2}\right) \\
\left(\mathrm{Fe}_{2} \mathrm{O}_{3}\right) \text {, minimum in \% }\end{array}$ & 70 & 50 \\
\hline Sulfur trioxide $\left(\mathrm{SO}_{3}\right)$, maximum in \% & 5 & 5 \\
\hline Moisture content, maximum in \% & 3 & 3 \\
\hline Loss of ignition, maximum in \% & 6 & 6 \\
\hline
\end{tabular}

Source: ASTM C 618 - 03 [1]

\subsection{Geopolymer paste}

Geopolymer has been growing very rapidly as a unique, important, and environmentally friendly material in building material industry and highway construction. Geopolymer has the advantage of easy to reach hardness or strength compared to conventional cement. The geopolymer increases the stability in acidic environments, is resistant to pressure, and is as resistant to fire and as it is to acid [2].

The geopolymer based on fly ash was conducted in concrete application. It used fly ash class F and Ordinary Portland Cement. The workability declined with addition of OPC content. The addition of OPC inclined the compressive strength. It also declined permeability at all ages (3, 7, 28 days). The geopolymer with $20 \%$ OPC produces optimum results (compressive and split tensile strength). The compact, dense and permeability in matrix were detected by XRD, SEM, EDS. The inclusion of OPC at different levels as fly ash replacement can improve the mechanical properties of geopolymer. The addition of OPC with low and very low permeability range improved chloride resistance of geopolymers [3].

The use of dredged sediments incorporating with fly ash can produce geopolymer matrices with improving mechanical properties. The materials made with dredged soil exhibit a more compact microstructure than with sand. It can be stated that it has better mechanical properties. It can be represented as a starting point for the beneficial use of polluted sediments in geopolymer matrices [4].

The geopolymer concrete can produce a high compressive strength, depending the fly ash quality. The compressive strength is not significantly affected by curing conditions when silica fume in comparison to sodium silicate is used as activating solution [5].

The compressive strength and workability of geopolymer concrete can be improved with silica fume addition. The flexural and tensile strength also increased with silica fume 
addition. It shows an increase in compactness and has denser microstructures. The quite durable materials of geopolymers concretes were obtained in the composition of $2 \% \mathrm{H}_{2} \mathrm{SO}_{4}$, $5 \% \mathrm{Na}_{2} \mathrm{SO}_{4}$ and $5 \% \mathrm{NaCl}[6]$.

The MSWI (Municipal Solid Waste Incineration) fly ash with L/S (Liquid to Solid) ratio of 10 and setting time of 2 hours was used in this research. The addition of cement of $67 \%$ and curing period of seven days produced the maximum compressive strength of 7.87 MPa. TCLP (Toxide Characteristic Leaching Procedure) test described that the solidified matrix can meet the requirement of landfill [7].

Materials consist of fly ash and brick powder. The parameter indicated the difference relation to ratio of fly ash to brick binder. The addition of MWCNTs increase the compressive strength and elastic modulus of geopolymer. The fracture toughness and fracture energy decreased with very small additions of MWCNTs [8].

The compositions ( $\mathrm{Si}$ to $\mathrm{Al}$ ratio of $2.2, \mathrm{Na}$ to $\mathrm{Al}$ ratio of $1.4, \mathrm{~W}$ to $\mathrm{S}$ ratio of 0.30 temperature of $40^{\circ} \mathrm{C}$ ) increase the setting time and workability of geopolymer. The compositions ( $\mathrm{Si}$ to $\mathrm{Al}$ ratio of $1.8, \mathrm{Na}$ to $\mathrm{Al}$ ratio of $1.0, \mathrm{~W}$ to $\mathrm{S}$ ratio of 0.20 and temperature of $80^{\circ} \mathrm{C}$ ) cause fastest setting time of geopolymer [9].

The increasing partial replacement of cement with fly ash of up to $30 \%$ increased the workability of fresh mortar mixture. It decreased the Super Plastisizer demand. The addition of silica fume up to $10 \%$ reduced the workability of the fresh mixture causing the increase in Super Plastisizer demand. The addition of calcium carbonate content up to $15 \%$ improved the workability of fresh mortar and compressive strength of mortar, mainly at early ages. The finer particle size of calcium carbonate increased compressive strength and the workability of mortar. The use of silica fume decreased the workability of fresh mortar. The addition of superplasticizer improved the workability [10].

The parameters significantly affect the behavior and microstructure of GPCs (Geopolymer Concretes). GPCs based on Bottom ash showed lower geopolymerization than GPCs based on fly ash [11]. The shrinkage decreased with slag content addition and decreased the SS/SH ratio in GPCs (the curing at room temperature). The age of GPCs of 180 days showed shrinkage of GPCs. It could be decreased to values within the limit of the Australian Standard [12].

Material is fly ash in East Java Indonesia. The advantages of fly ash utilization consist of reducing cost of material by decreasing cement utilization and reducing waste product from power plants. Low compressive strength was obtained from this research [13].

Materials used was Fly Ash and Fly Ash Blast Furnace Slag. The chemical composition of binding gel was correlated with optimal geopolymer strength. Both of the Alcali Activator systems indicate geopolymer technology development [14].

Materials used was Fly Ash and Bottom Ash. The application is conducted in geopolymer mortar and geopolymer concrete. Geopolymer based on fly ash has a compressive strength of 61.4 MPa and Young's Modulus of 2.9 GPa. Geopolymer based on bottom ash has a compressive strength of 55.2 $\mathrm{MPa}$ and Young's Modulus of $2.8 \mathrm{GPa}$. Geopolymer based on bottom ash exhibits a higher thermal conductivity of $0.85 \mathrm{~W} / \mathrm{mK}$ than geopolymers from fly ash of $0.58 \mathrm{~W} / \mathrm{mK}$ [15].

Material used was HVFA (very High Volume of Class F Fly Ash), the application in concrete. The setting time and air content of fly ash in concrete increased with the addition of fly ash replacement level. The compressive and flexural strength of HVFA concrete mixtures improve significantly at late ages from 91 and 365 days. The concrete containing low LOI fly ash showed superior mechanical properties than high LOI fly ash. Up to $80 \%$ of class F fly ash was according to cement replacement in concrete [16].

Material used was RHA (Rice Hush Ash) with control concrete at 28 days. The split tensile strength decreased by $9.58 \%$ in comparison with control concrete at 28 days. It can be reached with a composition of $22.5 \%$ FA and 2.5 RHA [17]. 
Material used was coal fly ash to form foamed geopolymeric materials, the application in concrete. The utilization of fly ash is an effort to reduce waste material and to protect the environment. The major chemical components of fly ash were $\mathrm{SiO}_{2}$ and $\mathrm{Al}_{2} \mathrm{O}_{3}$, with an amount of $82.06 \%$ of the total ash. It is important for geopolymer formation. The dissolution of $\mathrm{SiO}_{2}$ and $\mathrm{Al}_{2} \mathrm{O}_{3}$ appeared to increase with addition fly ash to $\mathrm{NaOH}$ contact time. The length of time the mixture was left in a slurry form before being placed in the oven affect the porosity of foamed geopolymers. Geopolymer formation shows $\mathrm{Si}-\mathrm{O}$ and Al-O stretching vibrations [18].

Material used was fly ash class F, application in concrete. The compressive strength of geopolymers increased with aging. The mechanical properties and microstructure of geopolymers were affected by curing temperature and time [19].

Material used was fly ash, the application in concrete. The main contribution for increasing the compressive strength of geopolymers is attributed to reduction of particle size and change in morphology of fly ash particles. The addition of free water in the mixtures decrease mechanical properties of geopolymers. The compressive strength of geopolymers after 28 days was $16 \mathrm{MPa}$ and $45 \mathrm{MPa}$ [20].

Material used was fly ash class F, application in concrete. The compressive strength is better than those achieved by hydraulic S/S methods that were obtained at 28 days. The geopolymer S/S solids showed in general a better behavior [21].

Materials consist of silica fume and fly ash class C to form SCC (Self Compacting Concrete), application in concrete. Self Compacting Concrete could be obtained with high volume fly ash, mainly with $10 \%$ Silica Fume replacement. Ten percent of Silica Fume additions affected positively both the fresh and hardened properties of high performance high volume fly ash SCC. The low cement in mixtures produce good mechanical properties, freeze-thaw and chloride penetration resistance [22].

Chemical property affects the strength of geopolymer paste was the Si to Al ratio. The research obtains that pastes have high compressive strength when Si to Al ratio were around two. When the Si to Al ratio are between 1.875 to 2.078 , the compressive strengths are between $44.39 \mathrm{MPa}$ and $50.30 \mathrm{MPa}$. Then the strength decrease as the increase of Si to Al ratio [23].

The fly ash type variation produced the different characterization. The $\mathrm{pH}$ and $\mathrm{CaO}$ content of fly ash contributes setting time of geopolymer paste. The fly ash particles morphology was mostly in spherical shape, the other hand the geopolymer paste morphology was bulky irregular shape [24]. The compressive strength of geopolymer paste whenever increases the soluble content of fly ash. The strength is influenced by physical and chemical characteristic of fly ash [25].

The benefit of geopolymer concrete was low maintenance cost since geopolymer concrete gives durable material. The study shows the compressive strength of geopolymer concrete increase with increase in molarity of alkaline solution [26].

The flexural strength of geopolymer ceramic was influenced by sodium hydroxide concentration, alkali activator ratio and the sintering temperature. The optimum flexural strength of geopolymer ceramic was obtained of alkali activator ratio of 0.24 , sodium hydroxide concentration at $12 \mathrm{M}$, the highest sintering temperature at $1200^{\circ} \mathrm{C} \mathrm{[27].}$

The increase of the fly ash content resulted in an increase in the compressive strength of the geopolymer concrete. The compressive strength of geopolymer concrete increases with the increase of sodium hydroxide concentration. The compressive strength of geopolymer concrete increase as sodium hydroxide concentration at M10 to M16. It is occurred that an increase of alkali concentration enhanced geopolymerization process so resulting to an increase in the compressive strength of geopolymer concrete [28].

The research shows an increased activators ratio result in a faster setting time, indicating the reaction rate of geopolymer was faster at higher activator ratios. The final setting time 
of Indonesian paste with activator ratios of 1.5, 2 and 2.5 were $12.9 \mathrm{~h}, 10.9 \mathrm{~h}$ and $7.3 \mathrm{~h} \mathrm{[29]}$ As compare to paste with $12 \mathrm{NaOH}$ system, application of $\mathrm{NaOH}$ solution of $14 \mathrm{M}$ generated the stronger matrix and faster the reaction [30].

The magnitude of bulk density, apparent porosity, Vickers microhardness and compressive strength of geopolymers produced through alkali activation of metakaolin are largely determined by the initial molar ratio of $\mathrm{Si} / \mathrm{Al}$ and $\mathrm{Na} / \mathrm{Al}$ [31]. $\mathrm{Si} / \mathrm{Al}$ and $\mathrm{Na} / \mathrm{Al}$ ratio of the starting materials play important roles in determining the mix design as well as the ultimate physical and microstructure characters of the resulting of geopolymers and intended applications [32].

\section{Method}

The method used in the experiment and laboratory investigation in Material and Concrete Laboratory ITS Surabaya. Material characterization was conducted in Material and Metallurgy Laboratory ITS Surabaya.

\subsection{Material}

Materials consist of fly ash, $\mathrm{NaOH}$ flake, distilled water and $\mathrm{Na}_{2} \mathrm{SiO}_{3}$. Fly ash was obtained from Suralaya Power Plant Indonesia. Fly ash was sieved by sieve No. 200. NaOH flake has a $99 \%$ purity and was produced by China. The grade of $\mathrm{Na}_{2} \mathrm{SiO}_{3}$ is $58 \%$. Distilled water was purchased at a chemical store in Surabaya. $\mathrm{NaOH}$ solution was made in 6 Molars and 8 Molars and was prepared one day before the mixing process. Preparation of $\mathrm{NaOH} 6$ Molars required 240 grams of $\mathrm{NaOH}$ flake per-1 liter of solution. While $\mathrm{NaOH} 8$ Molars required 320 grams of $\mathrm{NaOH}$ flake per-1 liter of solution. The solution was allowed for 24 hours in room temperature of $27-34^{\circ} \mathrm{C}$. Alkali activator was produced by mixing $\mathrm{NaOH} 6$ $\mathrm{M}$ or $8 \mathrm{M}$ with $\mathrm{Na}_{2} \mathrm{SiO}_{3}$. The ratio of $\mathrm{Na}_{2} \mathrm{SiO}_{3}$ to $\mathrm{NaOH}$ was 0.5 to 2.5 in increments of 0.5 . This solution was prepared one day before the mixing process. Figure 1 illustrated the materials preparation.
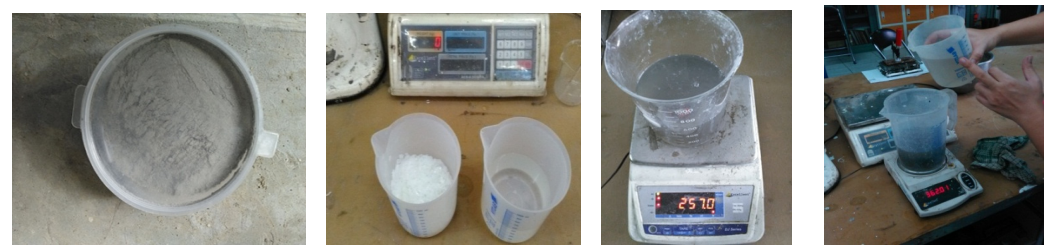

Fig. 1. Fly ash, $\mathrm{NaOH}$ flake, distilled water and $\mathrm{Na}_{2} \mathrm{SiO}_{3}$, and alkali activator producing process

\subsection{Process}

The process is illustrated in Figure 2.
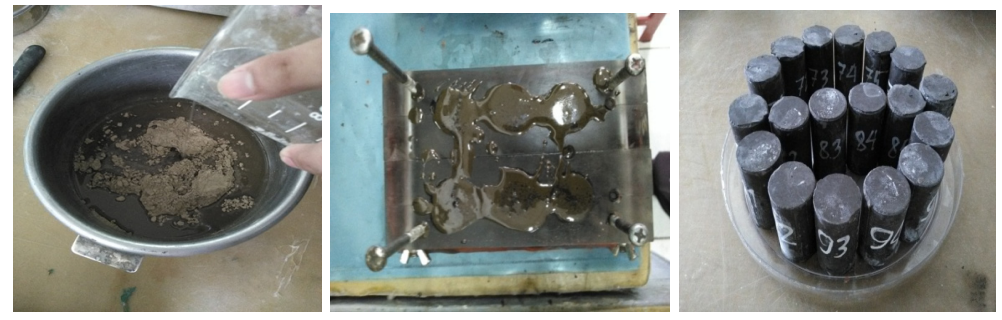

Fig. 2. Geopolymer paste producing 
Fly ash was mixed with alkali activator. The ratio of Solid to Liquid was 3 (about $75 \%$ of fly ash and $25 \%$ alkali activator). The mixture was stirred to obtain a homogeneous mixture. The geopolymer paste was casted in acrylic cylinders of $2 \mathrm{~cm}$ in diameter and 4 $\mathrm{cm}$ in height. The geopolymer paste was allowed for one day, and it was opened from the acrylic cylinder after 24 hours. The geopolymer paste was covered with wet cloth and was stored in a sealed container to keep its moisture. The geopolymer paste was stored for 28 days.

\subsection{Test}

A compressive strength test of the geopolymer paste was conducted at 28 days with Universal Testing Machine [1, 16, 22]. It is described in Figure 3. The capacity of the UTM in Material and Concrete Laboratory was 5 ton. The cylinder specimens were stored in an airtight box at room temperature. The specimen testing was conducted with 6 specimens of each variation.

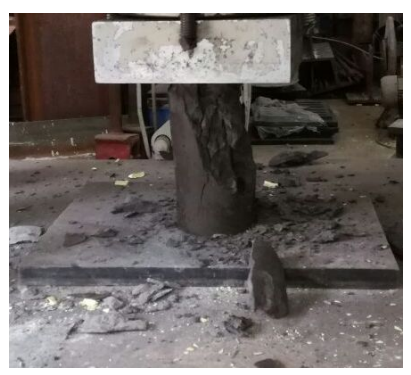

Fig. 3. Geopolymer paste testing

Fly ash test consists of XRF and SEM EDX. Geopolymer paste test consists of SEM EDX and compressive strength.

\section{Result and discussion}

\subsection{Material characteristic}

The result of XRF test can be presented in Table 2. This test was conducted to obtain the chemical composition of fly ash.

Table 2. XRF analysis ( $\%$ by mass)

\begin{tabular}{|c|c|c|c|c|c|c|c|c|c|c|}
\hline $\mathrm{SiO}_{2}$ & $\mathrm{Al}_{2} \mathrm{O}_{3}$ & $\mathrm{Fe}_{2} \mathrm{O}_{3}$ & $\mathrm{TiO}_{2}$ & $\mathbf{C a O}$ & $\mathbf{M g O}$ & $\mathrm{Cr}_{2} \mathbf{O}_{3}$ & $\mathrm{~K}_{\mathbf{2}} \mathbf{O}$ & $\mathrm{Na}_{2} \mathbf{O}$ & $\mathbf{S O}_{3}$ & $\mathbf{P}_{2} \mathrm{O}_{\mathbf{5}}$ \\
\hline 43.84 & 23.00 & 10.58 & 0.86 & 10.20 & 4.32 & 0.01 & 1.65 & 2.96 & 0.96 & 0.14 \\
\hline
\end{tabular}

According to data in Table 2 and ASTM C 618 - 03, fly ash from Suralaya unit 1-7 is classified $\mathrm{F}$ class. The largest component of fly ash is $\mathrm{SiO}_{2}$ of $43.84 \%$. The value of component $\mathrm{SiO}_{2}+\mathrm{Al}_{2} \mathrm{O}_{3}+\mathrm{Fe}_{2} \mathrm{O}_{3}$ is 77.42 (\% by weight), this value is more than $70 \%$. Fly ash class $\mathrm{F}$ or low calcium fly ash is the most excellent for producing geopolymer concrete. Fly ash class $\mathrm{F}$ with low calcium is more widely used as a source material when compared with fly ash class $\mathrm{C}$ with high calcium. The presence of high quantities of calcium in contrary to the polymerization process can change the microstructure condition. Fly ash containing $\mathrm{CaO}$ of less than $10 \%$ is produced from burning anthracite or bituminous coal (bituminous). 
Figure 4 provided the morphology of spherical particles of the ash by SEM analysis particle as well as the size variation of fly ash particles.

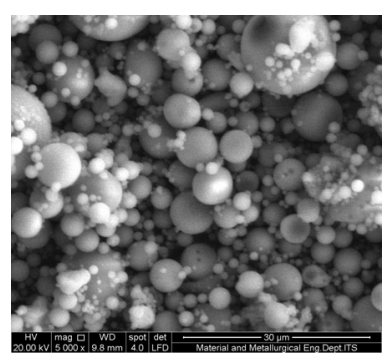

Fig. 4. SEM of fly ash.

The shape of the particles of fly ash is round and smooth. Particle size has variation between 1-10 $\mu \mathrm{m}$. Bright color indicates a constituent element that has a high atomic number, while dark color is a constituent element that has a low atomic number.

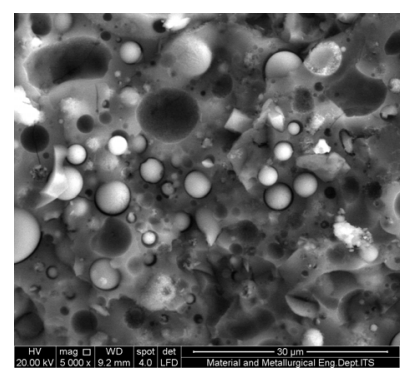

Fig. 5. SEM of geopolymer paste.

In Figure 5, SEM of geopolymer paste shows the merging of fly ash and alkali activator. However, it appears that some fly ash particle still has not reacted perfectly with the alkali activator.

\subsection{Compressive strength of geopolymer paste}

Compressive strength test of geopolymer paste was conducted with age of 28 days. The result of compressive strength test is presented in Table 3.

Table 3. Compressive strength of geopolymer paste.

\begin{tabular}{|c|r|r|}
\hline \multirow{2}{*}{$\mathbf{N a}_{2} \mathrm{SiO}_{3}$ to NaOH Ratio } & \multicolumn{2}{|c|}{ Compressive Strength (MPa) } \\
\cline { 2 - 3 } & $\mathbf{N a O H} 6 \mathbf{6 M}$ & \multicolumn{1}{c|}{$\mathbf{N a O H ~ 8 M}$} \\
\hline 0.5 & 71.1 & 88.1 \\
\hline 1.0 & 73.7 & 92.4 \\
\hline 1.5 & 74.8 & 91.0 \\
\hline 2.0 & 78.8 & 95.3 \\
\hline 2.5 & 77.3 & 98.6 \\
\hline
\end{tabular}

Figure 6 shows the relationship between the alkali activator ratio and the compressive strength of geopolymer paste. The samples with $\mathrm{NaOH} 8 \mathrm{M}$ produced the highest compressive strength which is $98.6 \mathrm{MPa}$. 


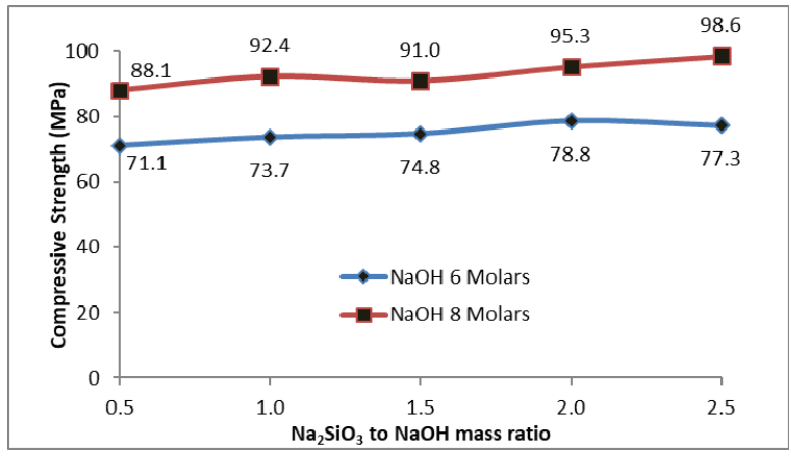

Fig. 6. Relationship between alkali activator ratio with compressive strength

In general, samples made with $\mathrm{NaOH} 8 \mathrm{M}$ is greater than those with $\mathrm{NaOH} 6 \mathrm{M}$. This is in line with the results of previous research which stated that higher molarity will also increase the compressive strength. Higher alkali activator ratio leads to an increasing of the compressive strength. The greatest compressive strength score was achieved with an alkaline activator ratio of 2.0 ratio of $78.8 \mathrm{MPa}$ with alkali of $6 \mathrm{M}$. The highest compressive strength score was achieved with an alkaline activator ratio of 2.5. This is due to the presence of more soluble silicate, heavier specimens, and greater density. The average specimen density is $2.02\left(\mathrm{gr} / \mathrm{cm}^{3}\right)$. Atomic ratios of $\mathrm{Si} / \mathrm{Al}$ at $6 \mathrm{M}$ and $8 \mathrm{M}$ were in the range between 1.74-1.89 which affected the strength of geopolymer paste. It is similar to the previous research $[23,33]$ where the highest strength was achieved when Si to Al ratio were around two.

\section{Conclusions}

The conclusions based on this study are as follows:

1. Fly ash from Suralaya 1-7 is classified as fly ash class F, where the total component of $\mathrm{SiO}_{2}, \mathrm{Al}_{2} \mathrm{O}_{3}, \mathrm{Fe}_{2} \mathrm{O}_{3}$ are 77.42 (\% by weight). Fly ash class $\mathrm{F}$ or low calcium fly ash is the most excellent for the production of fly ash geopolymer concrete.

2. The shape of the particles of fly ash is round and smooth. Particle size has size variation between 1-10 $\mu \mathrm{m}$. SEM of geopolymer paste shows the merging of fly ash and alkali activator. However, it appears that some fly ash still has not reacted perfectly with alkali activator. Bright color indicates a constituent element that has a high atomic number, while dark color is a constituent element that has a low atomic number.

3. The compressive strength of geopolymer paste shows a larger value with higher $\mathrm{NaOH}$ molarity. The highest compressive strength was obtained with $75 \%$ Fly Ash, $\mathrm{NaOH} 8 \mathrm{M}$ and alkali activator ratio of 2.5. This composition produces compressive strength of 98.6 MPa. The addition of $\mathrm{NaOH}$ molarity increases the compressive strength of geopolymer paste.

The research is supported by a degree scholarship from the Ministry of Technology Research and Higher Education collaborated with Ministry of Finance by LPDP/Fund Managers.

\section{References}

1 ASTM C 618 - 03 (Standard Specification for Coal Fly Ash and Raw or Calcined Natural Pozzolan for Use), 2 (2002). 
2 Bayuseno, A. P., Widyanto, S.A., Juwantono, Rotasi. 12, 10 (2010).

3 A. Mehta, R. Siddique, Constr. Build. Mater. 141, 325 (2017).

4 S. Lirer, B. Liguori, I. Capasso, A. Flora, D. Caputo, J. Environ. Manage. 191, 1-7 (2017).

L. N. Assi, E. Deaver, M. K. Elbatanouny, P. Ziehl, Constr. Build. Mater. 112, 807-815 (2016.)

6 F. N. Okoye, J. Durgaprasad, N. B. Singh, Data Br. 5, 739-744 (2015).

$7 \quad$ X. Wang, A. Li, Z. Zhang, Procedia Environ. Sci. 31, 440-446 (2016).

8 P. Rovnaník, H. Simonova, L. Topolar, P. Schmid, Z. Kersner, Procedia Eng 151, 321 (2016).

9 A. A. Siyal, K.A.. Azizli, Z. Man, H. Ullah, Procedia Eng. 148, 302 (2016).

10 Antoni, L. Chandra, D. Hardjito, Procedia Eng. 125, 773-779 (2015).

11 T. Xie, T. Ozbakkaloglu, Ceram. Int. 41, 5945-5958 (2015).

12 P. S. Deb, P. Nath, P.K. Sarker, Procedia Eng. 125, 594-600 (2015).

13 M. S. Darmawan, R. Bayuaji, N. A. Husin, Chomaedhi, I. Saud, Procedia Eng. 125, 579-586 (2015).

14 N. Marjanovi, M. Komljenovi, Z. Bašcarevic, V. Nikolic, Procedia Eng. 108, 231238 (2015).

15 E. Ul Haq, S. K. Padmanabhan, A. Licciulli, Ceram. Int. 40, 2965-2971 (2014).

16 C. H. Huang, S. K. Lin, C. S. Chang, H. J. Chen, Constr. Build. Mater. 46, 71-78 (2013).

17 S. H. Sathawane, V. S. Vairagade, K. S. Kene, Procedia Eng. 51, 35-44 (2013).

18 S. M. Nyale, O. O. Babajide, G. D. Birch, N. Böke, L. F. Petrik, Procedia Environ. Sci. 18, 722-730 (2013).

E. Arioz, O. Arioz, O. M. Kockar, Procedia Eng. 42, 1114-1120 (2012).

20 J. Temuujin, R. P. Williams, A. van Riessen, J. Mater. Process. Technol. 209, 5276-5280 (2009).

21 C. F. Pereira, Y. Luna, X. Querol, D. Antenucci, J. Vale, Fuel. 88, 1185-1193 (2009).

22 H. Yazici, Constr. Build. Mater. 22, 456-462 (2008).

23 A. L. Wijaya, J. J. Ekaputri, Triwulan, MATEC Web of Conf. 138, 01010 (2017).

24 P. Risdanareni, P. Puspitasari, J.J. Ekaputri, MATEC Web of Conf. 97, 01031 (2017).

25 R. Nurwidayati, M. B. Ulum, J. J. Ekaputri, P. Suprobo, Mater. Sci Forum. 841, 118-125 (2016).

26 K. Zerfu, J. J. Ekaputri, Mater. Sci. Forum. 841, 162-169 (2016).

27 N. A. Jaya, M. M. A. B., Abdullah, C.M.R., Ghazali, M. Binhussain, K. Hussin, R. Ahmad, J. J. Ekaputri, App. Mech. and Mater. 754-755, 152-156 (2015).

28 O. M. Omar, G. D. A. Elhameed, A. M. H. H. A. Mohamadien, Inter. J. of Civil, Environ, Struct, Constr. and Archi Eng. 9, 1345-1354 (2018).

Y. Tajunnisa, M. Sugimoto, T. Sato, J. J. Ekaputri, M. Shigeishi, Inter. Conf.:

Struct. Faults and Repair (2016).

30 J. J. Ekaputri, Triwulan, S. Junaedi, Fansuri, R. B. Aji, Mater. Sci Forum. 803, 6374 (2015). 
31 Subaer, J.J. Ekaputri, H. Fansuri, M.A.B. Abdullah, AIP Conf., 020170-1-8 (2017).

32 Subaer, A. Haris, Nurhayati, A. Irhamsyah, J.J. Ekaputri, Mater. Sci. Forum. 841, (2016).

33 Triani, D.N.D., Ekaputri, J.J., Triwulan, Hardono, S., Susanto, T.E., Mater. Sci. Forum. 841, 111-117 (2016). 